\title{
EFFECTS OF RIPENING STAGES AND STORAGE DURATIONS ON RESISTANCE PARAMETERS OF BEEF TYPE TOMATOES: PART 1: SPRING PERIOD
}

\author{
EFEITOS DE ESTÁGIOS DE MATURAÇÃO E DURAÇÕES DE ARMAZENAMENTO \\ EM PARAMETROS DE RESISTENNCIA DE TOMATES CORAÇÃO DE BOI: PARTE 1: \\ PERIOODO DE PRIMAVERA
}

\author{
Onder KABAS ${ }^{1}$; Aylin KABAS ${ }^{2}$; Sinan ZENGIN ${ }^{3}$; Serkan AYDIN ${ }^{4}$; Fatih Alpay VURAN ${ }^{4}$; \\ Can ERTEKIN ${ }^{5}$ \\ 1. Akdeniz University, Vocational School of Technical Science, Antalya, Turkey. onderkabas@hotmail.com; 2. Akdeniz University, \\ Manavgat Vocational School, Antalya, Turkey; 3. Antalya Agriculture Production Consultancy and Marketing Company, Antalya, \\ Turkey; 4. Bati Akdeniz Agricultural Research Institute, Antalya, Turkey; 5. Faculty of Agriculture, Department of Agricultural \\ Machinery and Technologies Engineering, Akdeniz University, Antalya, Turkey.
}

\begin{abstract}
Following the harvest, agricultural products are subjected to various negative impacts throughout the way to consumers. Mechanical damages such as color darkening, abrasion, cuts, or punctures over the fruit surface are irreversible damages and such damages ultimately end up in significant quality and economic losses. In modern production systems, only a certain portion of the products directly reach from producer to consumers. The majority of these products are subjected to mechanical damages through the crush, squeeze, vibration, and similar impacts during the harvest and postharvest processes. In this study, Tybeef tomato cultivar grown over the experimental greenhouses of Bati Akdeniz Agricultural Research Institute (BATEM) (control) and 14-193 and 14-206 coded candidate cultivars developed through breeding programs of BATEM were used as the plant material. Resistance parameters of tomato cultivars were determined at 4 different ripening stages (green, turning, pink, and red) and 4 different storage durations $(4,8,12$, and 16 days). Resistance parameters decreased with the progress of ripening and storage durations. All measurements and assessments revealed that 14-193 coded candidate cultivars were prominent for resistance parameters.
\end{abstract}

KEYWORDS: Damage. Harvest Date. Quality. Sensitivity. Vegetable.

\section{INTRODUCTION}

There are intense labor and input in agricultural commodities. Therefore, pre and postharvest processes should continuously be monitored to minimize yield losses, to have products complying with certain standards, to supply high-quality products to markets, and to improve the allure of the products. Physiological and biological deteriorations during the production, harvest, and postharvest processes result in significant losses both in the quality and quantity of the products and ultimately end up with significant economic losses for both the producers and the country (KABAS, 2002). Insufficient infrastructure and organization generate about $25 \%$ losses in productions and only $7-8 \%$ of total production is exported just because of losses in the quality of the products. Since standard and desired commodities are not able to be produced, it is quite hard to compete with other exporter countries in international markets. It should always be kept in mind that "quality at the table is more significant than the quality at the branch". Thus, all the processes from the field to consumers should be performed in the uppermost appropriate manner. High-quality products should preserve quality attributes for a long time and marketed abroad on demand. Such cases will automatically improve both the producer and the country's economy.

Postharvest losses are generally generated through mechanical damages. Such damages result from crash, impact, puncture, vibration, and similar mechanical processes. About 6.1 million tons of fresh vegetables and fruits are produced in the Antalya province of Turkey. About $75 \%$ of this production (4.6 million tons) is constituted by vegetables and tomato alone constitutes about 55\% of vegetable production of the province. About $62 \%$ of under-cover tomato production and $20 \%$ of openfield production of Turkey come from Antalya. About 3 million tons of fresh vegetables and fruit are exported from Turkey and, from those, 490 thousand tons are exported from Antalya alone (ANONYMOUS, 2018).

Mechanical damages may result in $30-40 \%$ 
losses throughout different processes from the field to consumers (PELEG; HINGA, 1986). Such damages are generally encountered through static and dynamic external forces like a crash, impact, squeeze, and vibration. Mechanical damages on agricultural products may vary with the physical and biological structure of the product and type of external forces. The damage is generally encountered as smash and fracture with the impact of crash forces and excessive deformations. Since agricultural products are living organisms, they are highly sensitive to mechanical damages. Damages during the transportation of agricultural products reduce their market values and make these products perishable and unstable for diseases and deteriorations (KARA; TURGUT, 1988). Therefore, the mechanical characteristics of agricultural products should be known to minimize such damages and losses accordingly.

Several researchers have conducted studies on different agricultural products (GEZER et al., 2000) investigated dimensional attributes, mass, removal force, mass/removal force ratio, total dissolved solids, fruit flesh firmness, and modulus of elasticity of tomato, pepper, eggplant and cucumbers and reported modules elasticity value of $1006 \mathrm{kPa}$ for tomato and $632 \mathrm{kPa}$ for cucumber (MOHSENIN, 1986) and (SITKEI, 1986) conducted studies on external damages generated by static and dynamic forces and identified various types of external damages. Desmet et al. (2004) investigated the mechanical characteristics of tomato and pointed out that genotypes with lower punching sensitivity should be used for direct measurements of mechanical characteristics. Bentini et al. (2009) investigated the effects of potato cultivars and storage durations on the physio-mechanical characteristics and indicated that mechanical characteristics of the different cultivars were significantly different from each other. Eraltan (2005) stored Dixired and Earlyred peaches in cold storage at $0{ }^{\circ} \mathrm{C}$ temperature and $90 \%$ relative humidity for 28 days to investigate the effects of cultivars and storage durations on mechanical attributes and reported decreasing peal tearing force, tearing energy, and firmness index with increasing storage durations. Garcia et al. (1995) investigated the effects of irrigation, moisture content, harvest time, and storage on fruit firmness peel characteristics, and damaging sensitivity of apple and pear species and put forth the relationships between fruit physical attributes and damaging. Schoorl and Holt (1983) studied the effects of storage durations and temperatures on the damaging sensitivity of Jonathan, Delicious, and Granny Smith apples.

Identification of resistance parameters of agricultural products constitutes valuable information for machine and equipment design, on one hand, aids in finding out the resistance of different agricultural products against mechanical forces and thus taking relevant measures accordingly on the other hand. In this study, the effects of 4 different fruit ripening stages (green, turning, pink, and red) and 4 different storage durations $(4,8,12$, and 16 days) on some resistance parameters of tomato were investigated.

\section{MATERIAL AND METHOD}

In this study, 3 different tomato cultivars (1 commercial cultivar - Tybeef and 2 candidate cultivars developed in tomato breeding programs of Bati Akdeniz Agricultural Research Institute (BATEM - 14-193, 14-206) were used as the plant material (Figure 1).
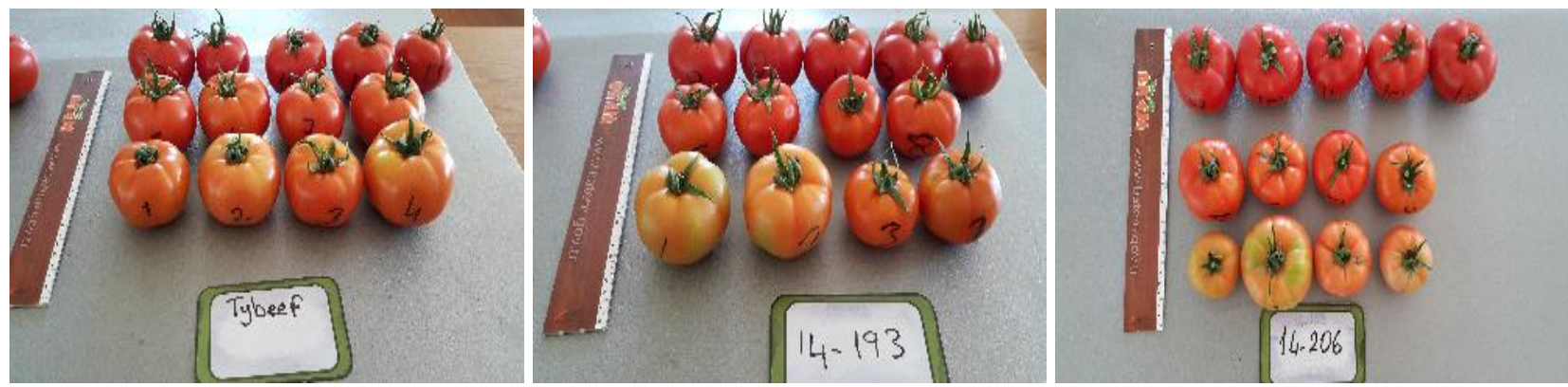

Figure. 1. Tybeef, 14-193,14-206 variety

Experiments were conducted at 4 different ripening stages and 4 different storage durations. The texture analysis test device was used to determine resistance parameters and a color measurement device was used to determine color parameters.

Experiments were conducted in two stages. The physical characteristics of tomatoes were determined in the first stage and resistance parameters were determined in the second stage of 
Effects of ripening...

the study. All measurements were performed at 4 different ripening stages (green, turning, pink, and red) and 4 different storage durations $(4,8,12$, and 16 days at $12^{\circ} \mathrm{C}$ temperature and $90 \%$ relative humidity).

For dimensional and shape characteristics, fruit length and diameters were measured with a digital caliper $( \pm 0.01 \mathrm{~mm})$. The following equations were used to calculate the geometric mean diameter and sphericity of the fruits (MOHSENIN, 1986) and (HACISEFEROGULLARI et al., 2005).

$\mathrm{Dg}=\left(\mathrm{LD}^{2}\right)^{1 / 3}$

$\mathrm{Dg}=$ Geometric mean diameter $(\mathrm{mm})$

$\mathrm{L}=$ Length $(\mathrm{mm})$

$\mathrm{D}=$ diameter of tomato $(\mathrm{mm})$

Sphericity was calculated dependent on geometric mean diameter using the following equation (MOHSENIN, 1986) and
KABAS, O. et al.

(HACISEFEROGULLARI et al., 2005).

$\Phi=(\mathrm{Dg} / \mathrm{L}) * 100$

$\Phi=$ Sphericity index (\%),

$\mathrm{Dg}=$ Geometric mean diameter $(\mathrm{mm})$,

$\mathrm{L}=$ Length $(\mathrm{mm})$

Also, the surface areas of tomato samples were determined by using the following formula (MOHSENIN, 1986).

$\mathrm{S}=\mathrm{Dg}^{2}$

$\mathrm{S}=$ Surface $\operatorname{area}\left(\mathrm{mm}^{2}\right)$,

$\mathrm{Dg}=$ Geometric mean diameter $(\mathrm{mm})$

A texture analysis device (probe diameter: 2 $\mathrm{mm}$, probe penetration rate: $10 \mathrm{~mm} \mathrm{~min}^{-1}$ ) was used to determine puncture force, maximum puncture strain, deformation, firmness, and modules of elasticity of tomato fruits (Figure 2).

Figure 2. Texture analysis device

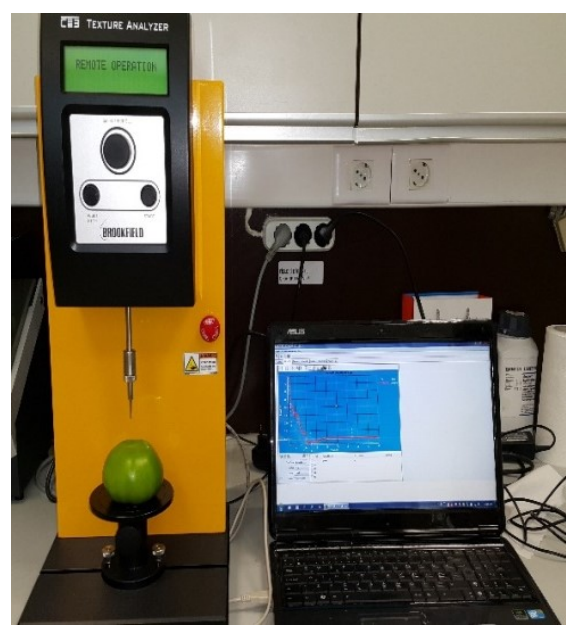

The tomato samples were placed on the base plate and pressed by the moving $2 \mathrm{~mm}$ diameter probe until the fruit punctured, and the forcedeformation curve was recorded in real-time for each experiment (Figure 3). Afterward, some resistance parameters such as deformation, force, and strain were extracted from each recorded curves.

For each cultivar, 50 fruits were used in experiments. Modules of elasticity and firmness were calculated with the aid of the following equations (NELSON; MOHSENIN, 1968; MOHSENIN, 1986; KABAS et al., 2008).

$E=\frac{F\left(1-\gamma^{2}\right)}{D . \Delta L}$
$\mathrm{E}=$ Modules of elasticity $\left(\mathrm{Nmm}^{-2}\right)$

$\mathrm{F}=$ Force $(\mathrm{N})$

$\gamma=$ Poisson ratio

$\mathrm{D}=$ Diameter of the cylindrical probe $(\mathrm{mm})$

$\Delta \mathrm{L}=$ Deformation $(\mathrm{mm})$

$Q=F / D$

$\mathrm{Q}=$ Firmness $\left(\mathrm{Nmm}^{-1}\right)$,

$\mathrm{F}=$ Maximum force $(\mathrm{N})$,

$\mathrm{D}=$ deformation in maximum force $(\mathrm{mm})$

The Peel color of tomatoes was measured with Minolta CR-100 chronometer (Minolta CR100, Osaka, Japan) device in accordance with $\mathrm{L}^{*}$, $a^{*}, b^{*}$ color space. Measurements were performed from 6 different sections of previously numbered 
Effects of ripening...

tomato fruits and averages of these measurements were taken. CIE L, a*, b*, chroma (C), and hue angle (ho) components of fruit color were analyzed with the aid of Minolta CR 400 (Konica Minolta) device (Figure 4). Measurements were made under the D65 light source. The device was calibrated with a calibration plate (CR A43) before the measurements (OZDEMIR, 2001). Minolta White color standard was used in calibrations. $\mathrm{L}^{*}$ indicates the changes in brightness of color. $\mathrm{L}^{*}$ gets maximum values as approached to 100 and such a value indicates a $100 \%$ reflection of the light sent to the color. The $\mathrm{a}^{*}$ indicates the color change from green to blue and the $b^{*}$ value indicates the color change from blue to yellow. Positive a* values
KABAS, O. et al.

indicate red and negative $\mathrm{a}^{*}$ values indicate green color; positive $b^{*}$ values indicate yellow and negative $b^{*}$ values indicate blue color. Increasing negative or positive values indicate color darkening.

\section{RESULTS AND DISCUSSION}

Experiments were set up with 1 commercial tomato cultivar (Tybeef) and 2 candidate tomato cultivars of BATEM (14-193 and 14-206) in the spring period in a greenhouse in randomized blocks design. Fruit physical characteristics including weight, diameter, length, geometric mean diameter (GMD), sphericity, and surface area are provided in Table 1.

Table 1. Physical characteristics of the cultivars

\begin{tabular}{llll}
\hline & Tybeef & $\mathbf{1 4 - 1 9 3}$ & $\mathbf{1 4 - 2 0 6}$ \\
\hline Weight $(\mathbf{g})$ & $334.40 \pm 8.190$ & $248.90 \pm 4.163$ & $282 \pm 2.865$ \\
Diameter $(\mathbf{m m})$ & $88.92 \pm 0.651$ & $85.21 \pm 0.732$ & $88.60 \pm 0.867$ \\
Length $(\mathbf{m m})$ & $75.84 \pm 0.673$ & $63.30 \pm 0.349$ & $68.84 \pm 0.549$ \\
GMD $(\mathbf{m m})$ & $80.60 \pm 0.420$ & $73.86 \pm 0.483$ & $77.85 \pm 0.430$ \\
Sphericity $(\%)$ & $106.58 \pm 0.911$ & $116.73 \pm 0.656$ & $113.45 \pm 1.135$ \\
Surface area $\left(\mathbf{m m}^{2}\right)$ & $20425.61 \pm 215.784$ & $17162.90 \pm 220.419$ & $19058.45 \pm 207.046$ \\
\hline
\end{tabular}

Tybeef was the heaviest cultivar with a fruit weight of $334 \mathrm{~g}$ and it was followed by 14-206 (282 g) and 14-193 (248 g) cultivars. The same order of cultivars was also valid for surface area, length, and geometric mean diameter. The order of cultivars for sphericity was 14-193 > 14-206 > Tybeef. Ponjičan et al. (2012) used hybrid industrial and table tomato cultivars and reported a sphericity value of $108 \%$ for table tomatoes and $83 \%$ for industrial tomatoes. Color analyses of cultivars were performed at 4 different ripening periods (green, turning, pink, and red) (Table 2).

Table 2. Color analysis of tomato variety according to ripening periods

\begin{tabular}{lllllll}
\hline Variety & Ripening period & $\mathbf{L}^{*}$ & $\mathbf{a}^{*}$ & $\mathbf{b}^{*}$ & $\mathbf{C}^{*}$ & $\mathbf{h}$ \\
\hline \multirow{4}{*}{ Tybeef } & Green & 56.59583 & -14.1792 & 26.955 & 30.45833 & 117.7483 \\
& Turning & 49.51288 & 12.50303 & 28.86887 & 31.86461 & 67.5616 \\
& Pink & 46.44112 & 21.59205 & 31.21651 & 38.18437 & 55.63898 \\
& Red & 42.88548 & 27.99544 & 33.51827 & 41.14655 & 49.0069 \\
\hline \multirow{4}{*}{$\mathbf{1 4 - 2 0 6}$} & Green & 61.0003 & -13.8225 & 27.5175 & 30.79583 & 116.6958 \\
& Turning & 53.9038 & 9.222059 & 32.01636 & 33.5309 & 74.24977 \\
& Pink & 48.80256 & 22.19618 & 32.24586 & 43.48071 & 59.36307 \\
& Red & 42.01052 & 27.89648 & 30.58708 & 41.42207 & 47.68977 \\
\hline \multirow{4}{*}{$\mathbf{1 4 - 1 9 3}$} & Green & 64.8925 & -13.8708 & 28.955 & 32.10917 & 115.6192 \\
& Turning & 51.03345 & 16.67125 & 35.25025 & 39.40221 & 65.74004 \\
& Pink & 42.55084 & 28.08351 & 31.65187 & 42.45265 & 48.23326 \\
& Red & 40.42044 & 29.75215 & 28.65868 & 41.31484 & 43.91488 \\
\hline
\end{tabular}

Color graphs for different ripening stages were presented in the order of red, pink, turning, and green. Mean a* value of Tybeef F1 was 27.995 for red tomatoes, 21.592 for pink tomatoes, 12.503 for turning tomatoes, and -14.179 for green tomatoes.
Mean a* value of 14-206 cultivar was 27.896 for red tomatoes, 22.196 for pink tomatoes, 9.222 for turning tomatoes, and -13.822 for green tomatoes. Mean a* value of 14-193 cultivar was 29.752 for red tomatoes, 28.083 for pink tomatoes, 16.671 for 
turning tomatoes, and -13.870 for green tomatoes. The greatest and the lowest $\mathrm{a}^{*}$ values (27.995 and 14.179) were observed in the Tybeef F1 cultivar. Ye and Zhang (2018) reported the greatest $a^{*}$ value as 31.240 and the lowest $a^{*}$ value as -12.62 . Present findings revealed that $\mathrm{a}^{*} / \mathrm{b}^{*}$ ratio was also an important indicator for changing resistance parameters. Similar findings were also reported by Camelo and Gómez (2004).

The data were analyzed based on ripening stages. There were significant differences in the puncture force of the cultivars at a 5\% level. The data on the puncture force are provided in Table 3.

Table 3. Variance table for puncture force $(\mathrm{N})$

\begin{tabular}{lrrrr}
\hline Source of Variance & Sum of Squares & Mean Squares & F value & \\
\hline Cultivar & 123.5493 & 44.8428 & $<0.0001$ & $* *$ \\
Replicate & 23.6189 & 8.5726 & 0.0003 & $* *$ \\
Ripening & 4174.2611 & 1010.044 & $<0.0001$ & $* *$ \\
Storage & 975.1566 & 176.9687 & $<0.0001$ & $* *$ \\
Cultivar*Storage & 21.5991 & 1.9599 & 0.0574 & $\mathrm{~ns}$ \\
Cultivar*Ripening & 38.4993 & 4.6578 & 0.0003 & $* *$ \\
Ripening*Storage & 263.8993 & 15.9639 & $<0.0001$ & $* *$ \\
Cultivar*Ripening*Storage & 48.6798 & 1.4724 & 0.0905 & $\mathrm{~ns}$ \\
\hline$*: 05, * *: 0.01$, ns: Not-significant & & & &
\end{tabular}

Variance analysis revealed that cultivars, ripening stages, and storage durations had significant effects on puncture forces at a $1 \%$ level. Cultivar*ripening stage and storage duration*ripening stage interactions had also significant effects on puncture forces $(p<0.01)$, but the effects of cultivar*storage duration*ripening stage triple interactions were not found to be significant. There were interactions between the cultivars and varieties in the turning phase of tomatoes. Interaction data are provided in Table 4.

Table 4. Cultivar*ripening stage interaction table for puncture force $(\mathrm{N})$

\begin{tabular}{llllll}
\hline Cultivar & Green & Turning & Pink & Red & Mean \\
\hline Tybeef & $21.25 \mathrm{c}$ & $12.85 \mathrm{~b}$ & $10.77 \mathrm{~b}$ & $9.72 \mathrm{~b}$ & $13.65 \mathbf{C}$ \\
$\mathbf{1 4 - 1 9 3}$ & $24.62 \mathrm{a}$ & $14.54 \mathrm{a}$ & $12.24 \mathrm{a}$ & $11.3 \mathrm{a}$ & $15.68 \mathrm{~A}$ \\
$\mathbf{1 4 - 2 0 6}$ & $22.58 \mathrm{~b}$ & $12.63 \mathrm{~b}$ & $11.65 \mathrm{a}$ & $11.41 \mathrm{a}$ & $14.57 \mathbf{B}$ \\
Mean & $22.82 \mathrm{~A}$ & $13.34 \mathbf{B}$ & $11.55 \mathrm{C}$ & $10.81 \mathrm{D}$ &
\end{tabular}

$\mathrm{CV}(\%)=8.02 ;$ Cultivar LSD $(0.05)=0.42$; Ripening stage LSD $(0.05)=0.49$; Cultivar*Ripening Stage interaction LSD $(0.05)=0.848$

The greatest puncture force $(24.62 \mathrm{~N})$ was observed in the green ripening stage of 14-193 cultivar and the lowest puncture force $(9.72 \mathrm{~N})$ was observed in the red ripening stage of the Tybeef cultivar. Considering the ripening stages, the greatest puncture force was observed in green tomatoes. With regard to cultivar*ripening stage interactions, 14-193 cultivar was prominent in all ripening stages.

The greatest puncture forces were observed in green tomatoes and the lowest values were observed in red tomatoes since fruit firmness decreased with the progress of ripening. Similar findings were also reported by Sirisomboon et al. (2012) indicating decreasing firmness values from green to red tomatoes.

There were interactions between storage durations of the cultivars and the ripening stage.
Interaction data are shown in Table 5.

Considering the storage duration*ripening stage interactions, the greatest puncture force $(26.76$ $\mathrm{N})$ was observed in the green ripening stage of 0 day storage and the lowest puncture force $(9.06 \mathrm{~N})$ was observed in the turning ripening stage of 16-day storage. Considering the storage durations, the greatest puncture force was observed in 16-day storage. Puncture resistance decreased with the progress of ripening and storage durations. Similar findings were also reported for tomatoes by Yurtlu and Erdogan (2005) and Bui et al. (2010). Such a case indicated that fruits were more sensitive to physical damages at early ripening stages. 
Table 5. Ripening stage*storage duration interaction table for puncture force $(\mathrm{N})$

\begin{tabular}{lllll}
\hline Storage Duration & Green & Turning & Pink & Red \\
\hline 0 day & $26.76 \mathrm{a}$ & $20.39 \mathrm{a}$ & $13.56 \mathrm{a}$ & $12.77 \mathrm{a}$ \\
$\mathbf{4}$ days & $25.09 \mathrm{~b}$ & $13.93 \mathrm{~b}$ & $12.29 \mathrm{~b}$ & $11.47 \mathrm{~b}$ \\
$\mathbf{8}$ days & $22.89 \mathrm{c}$ & $12.58 \mathrm{c}$ & $11.39 \mathrm{c}$ & $10.83 \mathrm{~b}$ \\
$\mathbf{1 2}$ days & $21.20 \mathrm{~d}$ & $10.75 \mathrm{~d}$ & $10.8 \mathrm{c}$ & $9.81 \mathrm{bc}$ \\
$\mathbf{1 6}$ days & $18.08 \mathrm{e}$ & $9.06 \mathrm{e}$ & $9.73 \mathrm{~cd}$ & $9.17 \mathrm{c}$ \\
\hline
\end{tabular}

$\mathrm{CV}(\%)=8.01$; Storage duration LSD $(0.05)=0.54$; Storage duration*Ripening stage interaction LSD $(0.05)=1.089$

The variance table for strain values is provided in Table 6 . There were significant differences in strain values of the cultivars at a $5 \%$ level.

Table 6. Variance table of strain $\left(\mathrm{Nmm}^{-2}\right)$

\begin{tabular}{lrrrr}
\hline Source of Variance & Sum of Squares & Mean Squares & F value & \\
\hline Cultivar & 7.72183 & 44.8428 & $<.0001$ & $* *$ \\
Replicate & 1.47618 & 8.5726 & 0.0003 & $* *$ \\
Ripening & 260.89132 & 1010.044 & $<.0001$ & $* *$ \\
Storage & 60.94729 & 176.9687 & $<.0001$ & $* *$ \\
Cultivar*Storage & 2.40621 & 1.9599 & 0.0574 & n. S \\
Cultivar*Ripening & 1.34994 & 4.6578 & 0.0003 & $* *$ \\
Ripening*Storage & 16.49371 & 15.9639 & $<.0001$ & $* *$ \\
Cultivar*Ripening*Storage & 3.04248 & 1.4724 & 0.0905 & n. S \\
\hline$*: 0.05, * *: 0.01$, ns: Not-significant & & & &
\end{tabular}

Variance analysis revealed that cultivars, replicates, ripening stages, and storage durations had significant effects on strain values at a $1 \%$ level. Considering the interactions, cultivar*ripening stage and storage duration*ripening stage interactions were also found to be significant $(p<0.01)$, but cultivar*storage duration and cultivar*storage duration*ripening stage triple interaction did not have significant effects on strain values.

There were interactions between the cultivars and storage durations in turning the ripening stage. Interaction data are provided in Table 7.

Table 7. Cultivar*Ripening stage interaction table for strain $\left(\mathrm{Nmm}^{-2}\right)$

\begin{tabular}{llllll}
\hline Cultivar & Green & Turning & Pink & Red & Mean \\
\hline Tybeef & $5.31 \mathrm{c}$ & $3.21 \mathrm{e}$ & $2.69 \mathrm{~h}$ & $2.43 \mathrm{1}$ & $5.31 \mathrm{c}$ \\
$\mathbf{1 4 - 1 9 3}$ & $6.15 \mathrm{a}$ & $3.64 \mathrm{~d}$ & $3.06 \mathrm{ef}$ & $2.83 \mathrm{gh}$ & $6.15 \mathrm{a}$ \\
$\mathbf{1 4 - 2 0 6}$ & $5.65 \mathrm{~b}$ & $3.16 \mathrm{e}$ & $2.91 \mathrm{fg}$ & $2.85 \mathrm{fgh}$ & $5.65 \mathrm{~b}$ \\
Mean & $5.71 \mathrm{~A}$ & $3.34 \mathrm{~B}$ & $2.89 \mathrm{C}$ & $2.70 \mathrm{D}$ & \\
\hline
\end{tabular}

$\mathrm{CV}(\%)=8.02$; Cultivar LSD $(0.05)=0.42$; Ripening stage LSD $(0.05)=0.49$; Cultivar*Ripening Stage interaction LSD $(0.05)=0.848$

The greatest strain value $\left(6.15 \mathrm{Nmm}^{-2}\right)$ was observed in the green ripening stage of 14-193 cultivar and the lowest strain value $\left(2.43 \mathrm{Nmm}^{-2}\right)$ was observed in the red ripening stage of the Tybeef cultivar (Table 7). Considering the strain values of ripening stages, the greatest value was observed in green tomatoes. Considering the cultivar*ripening stage interactions, 14-193 was prominent in all ripening stages. The greatest strain values were observed in green tomatoes and the lowest values were observed in red tomatoes since initial fruit firmness decreased with the progress of ripening.
Similar findings were also reported by Sirisomboon et al. (2012). There were interactions between the ripening stage and storage durations. Interaction data are provided in Table 8 . 
Table 8. Ripening stage* storage duration interaction table for strain $\left(\mathrm{Nmm}^{-2}\right)$

\begin{tabular}{llllll}
\hline Storage duration & Green & Turning & Pink & Red & Mean \\
\hline 0 day & $6.69 \mathrm{a}$ & $5.10 \mathrm{~d}$ & $3.39 \mathrm{fg}$ & $3.19 \mathrm{gh}$ & 4.59 \\
$\mathbf{4}$ days & $6.27 \mathrm{~b}$ & $3.48 \mathrm{f}$ & $3.08 \mathrm{~h} 1$ & $2.87 \mathrm{j}$ & 3.93 \\
8 days & $5.72 \mathrm{c}$ & $3.15 \mathrm{gh}$ & $2.85 \mathrm{ij}$ & $2.71 \mathrm{jk}$ & 3.61 \\
$\mathbf{1 2}$ days & $5.32 \mathrm{~d}$ & $2.69 \mathrm{jkl}$ & $2.70 \mathrm{jkl}$ & $2.46 \mathrm{klm}$ & 3.29 \\
$\mathbf{1 6}$ days & $4.52 \mathrm{e}$ & $2.29 \mathrm{~m}$ & $2.43 \mathrm{~lm}$ & $2.27 \mathrm{~m}$ & 2.88 \\
\hline
\end{tabular}

$\mathrm{CV}(\%)=8.01$; Storage duration LSD $(0.05)=0.14$; Storage duration*Ripening stage LSD $(0.05)=0.55$

Considering the storage duration*ripening stage interactions, the greatest strain value (6.69 $\mathrm{Nmm}^{-2}$ ) was observed in the green ripening stage of 0 -day storage and the lowest strain value (2.27 $\mathrm{Nmm}^{-2}$ ) was observed in the red ripening stage of 16-day storage. Considering the storage durations, the lowest puncture force was observed in 16-day storage. The resistance of tomatoes decreased with the progress of ripening stages and storage durations. Yurtlu and Erdogan (2005) also reported similar findings for tomatoes. Ciupak et al. (2012) investigated the effects of ripening on tomato cultivars and indicated that damaging strain decreased with the progress of ripening.

The variance table for deformation values is provided in Table 9. A separate analysis was performed for each ripening stage and differences in deformation values of the cultivars were not found to be significant at a $5 \%$ level.

Table 9. Variance table for deformation (mm)

\begin{tabular}{lllll}
\hline Source of Variance & Sum of Squares & Mean Squares & F value & \\
\hline Cultivar & 2.83794 & 2.9150 & 0.0581 & $*$ \\
Replicate & 30.41596 & 31.2420 & $<.0001$ & $* *$ \\
Ripening & 162.67909 & 111.3981 & $<.0001$ & $* *$ \\
Storage & 125.66719 & 64.5401 & $<.0001$ & $* *$ \\
Cultivar*Storage & 2.33291 & 0.7988 & 0.5728 & $\mathbf{n s}$ \\
Cultivar*Ripening & 3.61340 & 0.9279 & 0.4963 & $\mathbf{n s}$ \\
Ripening*Storage & 19.37272 & 3.3165 & 0.0004 & $* *$ \\
Cultivar*Ripening*Storage & 10.67492 & 0.9137 & 0.5834 & $\mathbf{n s}$ \\
\hline
\end{tabular}

*: $0,05, * *: 0,01, \mathrm{~ns}$ : Not-significant

However, there were significant differences in deformation values of the storage durations at a
$5 \%$ level. Interaction data are provided in Table 10.

Table 10. Ripening stage*storage duration interaction table for deformation (mm)

\begin{tabular}{llllll}
\hline Storage Duration & Green & Turning & Pink & Red & Mean \\
\hline 0 day & $3.93 \mathrm{j}$ & $5.43 \mathrm{fgh}$ & $5.31 \mathrm{gh}$ & $5.69 \mathrm{efg}$ & $5.09 \mathrm{E}$ \\
4 day & $4.26 \mathrm{ij}$ & $5.61 \mathrm{efg}$ & $5.81 \mathrm{efg}$ & $6.03 \mathrm{ef}$ & $5.43 \mathrm{D}$ \\
8 day & $4.42 \mathrm{ij}$ & $6.01 \mathrm{ef}$ & $6.16 \mathrm{de}$ & $6.69 \mathrm{c}$ & $5.90 \mathrm{C}$ \\
12 day & $4.65 \mathrm{i}$ & $6.80 \mathrm{~cd}$ & $6.99 \mathrm{~cd}$ & $7.16 \mathrm{c}$ & $6.40 \mathrm{~B}$ \\
16 day & $4.86 \mathrm{hi}$ & $7.84 \mathrm{~b}$ & $8.46 \mathrm{ab}$ & $8.70 \mathrm{a}$ & $7.47 \mathrm{~A}$ \\
Mean & $4.42 \mathrm{C}$ & $6.34 \mathrm{~B}$ & $6.55 \mathrm{~B}$ & $6.85 \mathrm{~A}$ & \\
\hline
\end{tabular}

$\mathrm{CV}(\%)=11.54$; Ripening stage $\operatorname{LSD}(0.05)=0.29$; Storage duration LSD $(0.05)=0.32$; Storage duration*Ripening

Variance analysis revealed that replicates, ripening stages, and storage durations had significant effects on deformation at a $1 \%$ level, but the effects of cultivars were not found to be significant. Considering the interactions, cultivar*ripening stage, storage duration*ripening stage, and cultivar*storage duration*ripening stage interactions were not found to be significant, but ripening stage*storage duration interaction was found to be significant $(p<0.01)$.

With regard to deformation values of storage duration*ripening stage interactions, the lowest value was observed in the green ripening stage of 0-day storage (control) and the greatest 
value was observed in the red ripening stage of 16day storage. Considering the storage durations, the greatest deformation was observed in 16-day storage. Deformation increased with the progress of ripening stages and storage durations. Yurtlu and Erdogan (2005) also reported similar deformation values for tomatoes in their study.

The variance table for firmness values is provided in Table 11. There were significant differences in the firmness values of the cultivars at a $5 \%$ level.

Table 11. Variance table for firmness $\left(\mathrm{Nmm}^{-1}\right)$

\begin{tabular}{lllll}
\hline Source of Variance & Sum of Squares & Mean Squares & F value & \\
\hline Cultivar & 2.55469 & 8.1044 & 0.0005 & $* *$ \\
Replicate & 2.69858 & 8.5609 & 0.0003 & $* *$ \\
Ripening & 386.49221 & 817.3983 & $<.0001$ & $* *$ \\
Storage & 94.39840 & 149.7335 & $<.0001$ & $* *$ \\
Cultivar*Storage & 1.50794 & 1.5946 & 0.1547 & $\mathrm{~ns}$ \\
Cultivar*Ripening & 2.17381 & 1.7240 & 0.0997 & $\mathrm{~ns}$ \\
Ripening*Storage & 14.51595 & 7.6750 & $<.0001$ & $* *$ \\
Cultivar*Ripening*Storage & 3.57555 & 0.9452 & 0.5421 & $\mathrm{~ns}$ \\
\hline$*: 0,05, * *: 0,01$, ns: not-significant & & &
\end{tabular}

Variance analysis revealed that cultivars, replicates, ripening stages, and storage durations had significant effects on firmness values at a $1 \%$ level. Considering the interactions, cultivar*ripening stage, storage duration*ripening stage, and cultivar*storage duration*ripening stage interactions were not found to be significant, but ripening stage* storage duration interaction had significant effects on firmness values $(\mathrm{p}<0.01)$.

There were interactions between the cultivars and the ripening stage. Interaction data are provided in Table 12.

Table 12. Cultivar*Ripening stage interaction table for firmness $\left(\mathrm{Nmm}^{-1}\right)$

\begin{tabular}{llllll}
\hline Cultivar & Green & Turning & Pink & Red & Mean \\
\hline Tybeef & 5.01 & 4.52 & 3.48 & 3.16 & $\mathbf{5 . 2 8}$ B \\
$14-193$ & 5.56 & 4.88 & 3.96 & 3.44 & $\mathbf{5 . 8 4} \mathbf{A}$ \\
$14-206$ & 5.24 & 4.08 & 3.72 & 3.36 & $\mathbf{5 . 4 0} \mathbf{B}$ \\
Ort. & $\mathbf{5 . 2 6} \mathbf{A}$ & $\mathbf{4 . 4 8} \mathbf{B}$ & $\mathbf{3 . 7 2} \mathbf{C}$ & $\mathbf{3 . 3 2} \mathbf{D}$ & \\
\hline
\end{tabular}

$\mathrm{CV}(\%)=14.36$; Cultivar LSD $(0.05)=0.07$; Ripening stage LSD $(0.05)=0.08$; Cultivar*Ripening Stage interaction $=$ n. $\mathrm{s}$

There were interactions between the

data are shown in Table 13.

ripening stage and storage durations. Interaction

Table 13. Ripening stage*Storage duration interaction table for firmness $\left(\mathrm{Nmm}^{-1}\right)$

\begin{tabular}{llllll}
\hline Storage Duration & Green & Turning & Pink & Red & Mean \\
\hline 0 day & $6.87 \mathrm{a}$ & $3.80 \mathrm{a}$ & $2.60 \mathrm{a}$ & $2.30 \mathrm{a}$ & $3.89 \mathrm{~A}$ \\
$\mathbf{4}$ days & $5.97 \mathrm{~b}$ & $2.52 \mathrm{~b}$ & $2.12 \mathrm{~b}$ & $1.93 \mathrm{~b}$ & $3.14 \mathrm{~B}$ \\
$\mathbf{8}$ days & $5.19 \mathrm{c}$ & $2.15 \mathrm{c}$ & $1.86 \mathrm{c}$ & $0.82 \mathrm{c}$ & $2.71 \mathrm{C}$ \\
$\mathbf{1 2}$ days & $4.60 \mathrm{c}$ & $1.60 \mathrm{~d}$ & $1.56 \mathrm{~d}$ & $1.38 \mathrm{~d}$ & $2.29 \mathrm{D}$ \\
$\mathbf{1 6}$ days & $3.74 \mathrm{~d}$ & $1.17 \mathrm{e}$ & $1.15 \mathrm{e}$ & $1.06 \mathrm{e}$ & $1.78 \mathrm{E}$ \\
Mean & $5.26 \mathrm{~A}$ & $2.24 \mathrm{~B}$ & $1.86 \mathrm{C}$ & $1.66 \mathrm{D}$ & \\
\hline
\end{tabular}

$\mathrm{CV}(\%)=14.36$; Ripening stage LSD $(0.05)=0.08$ Storage duration LSD $(0.05)=0.09$; Storage duration*Ripening stage interaction.

With regard to firmness values of storage duration*ripening stage interactions, the greatest value was observed in the green ripening stage of 0 day storage and the lowest value was observed in the red ripening stage of 16-day storage. Considering the storage durations, the lowest deformation was observed in 16-day storage. Fruit firmness decreased with the progress of ripening. Similar results were also reported by Kaynas and Surmeli (1995). Puncture test data revealed that ripening stages had significant effects on firmness values. Olorunda and Tung (1985) reported fruit 
firmness of tomatoes as $0.549 \mathrm{~kg} \mathrm{~mm}^{-1}$ in their research. Such a value was similar to the values for the present red ripening stage. Ince et al. (2016) indicated that the easiest harvest was performed when the tomatoes had firmness values of between
$1.55-2.00 \mathrm{Nmm}^{-1}$

Data on the modulus of elasticity are provided in Table 14. There were significant differences in modulus of elasticity values of the cultivars at a $5 \%$ level.

Table 14. Variance table for modulus of elasticity $\left(\mathrm{Nmm}^{-2}\right)$

\begin{tabular}{lllll}
\hline Source of Variance & Sum of Squares & Mean Squares & F value & \\
\hline Cultivar & 0.159668 & 8.1044 & 0.0005 & $* *$ \\
Replicate & 0.168661 & 8.5609 & 0.0003 & $* *$ \\
Ripening & 24.155763 & 817.3983 & $<.0001$ & $* *$ \\
Storage & 5.899900 & 149.7335 & $<.0001$ & $* *$ \\
Cultivar*Storage & 0.094246 & 1.5946 & 0.1547 & $\mathrm{~ns}$ \\
Cultivar*Ripening & 0.135863 & 1.7240 & 0.0997 & $\mathrm{~ns}$ \\
Ripening*Storage & 0.907247 & 7.6750 & $<.0001$ & $* *$ \\
Cultivar*Ripening*Storage & 0.223472 & 0.9452 & 0.5421 & $\mathrm{~ns}$ \\
\hline
\end{tabular}

*: $0,05, * *: 0,01$, ns: not-significant

Variance analysis revealed that cultivars, replicates, ripening stages, and storage durations had significant effects on the modulus of elasticity values at a $1 \%$ level. While cultivar*ripening stage and cultivar*storage duration*ripening stage interactions were not found to be significant, ripening stage*storage duration interactions had significant effects on the modulus of elasticity $(\mathrm{p}<0.01)$.
There were interactions between the cultivars and the ripening stage. Interaction data are provided in Table 15. Sirisomboon et al. (2012) reported the modulus of elasticity of ripe tomatoes as $0.90 \mathrm{Nmm}^{-2}$ and Kabas and Ozmerzi (2008) reported modules of elasticity of cherry tomatoes as between $0.16-0.28 \mathrm{Nmm}^{-2}$.

Table15. Cultivar*ripening stage interaction table for modulus of elasticity $\left(\mathrm{Nmm}^{-2}\right)$

\begin{tabular}{llllll}
\hline Cultivar & Green & Turning & Pink & Red & Mean \\
\hline Tybeef & 1.25 & 0.56 & 0.44 & 0.39 & $0.66 \mathrm{~B}$ \\
$14-193$ & 1.39 & 0.61 & 0.49 & 0.43 & $0.73 \mathrm{~A}$ \\
$14-206$ & 1.31 & 0.51 & 0.46 & 0.42 & $0.68 \mathrm{~A}$ \\
Mean & $1.32 \mathrm{~A}$ & $0.56 \mathrm{~B}$ & $0.46 \mathrm{C}$ & $0.41 \mathrm{D}$ & \\
\hline CV $(\%)=14.30 ;$ Cultivar LSD $(0.05)=0.0035 /$ Ripening stage LSD $(0.05)=0.04 ;$ & Cultivar*Ripening stage interaction $=$ ns
\end{tabular}

There were interactions between the ripening stage and storage durations. Interaction data are provided in Table 16. Considering the storage duration*ripening stage interactions, the greatest modulus of elasticity was observed in the green ripening stage of 0-day storage (control) and the lowest value was observed in the red ripening stage of 16-day storage (Table 16). Considering the storage durations, the lowest modulus of elasticity was observed in 16-day storage. Yurtlu and Erdogan (2005) reported modules of elasticity of tomatoes as between $0.18-0.13 \mathrm{Nmm}^{-2}$ for EF49 cultivar and as between $0.14-0.40 \mathrm{Nmm}^{-2}$ for the Joker cultivar. Yurtlu and Erdogan (2005) investigated the effects of ripening on tomato cultivars and reported decreasing modulus of elasticity with the progress of ripening. 
Table 16. Storage durations*ripening stage interaction table for modulus of elasticity $\left(\mathrm{Nmm}^{-2}\right)$

\begin{tabular}{llllll}
\hline Storage Duration & Green & Turning & Pink & Red & Mean \\
\hline 0 day & $1.71 \mathrm{a}$ & $0.95 \mathrm{e}$ & $0.65 \mathrm{f}$ & $0.57 \mathrm{fgh}$ & $0.97 \mathrm{~A}$ \\
4 days & $1.49 \mathrm{~b}$ & $0.63 \mathrm{fg}$ & $0.53 \mathrm{hi}$ & $0.48 \mathrm{ij}$ & $0.78 \mathrm{~B}$ \\
8 days & $1.30 \mathrm{c}$ & $0.54 \mathrm{ghi}$ & $0.46 \mathrm{ij}$ & $0.41 \mathrm{jk}$ & $0.68 \mathrm{C}$ \\
12 days & $1.15 \mathrm{~d}$ & $0.40 \mathrm{jkd}$ & $0.39 \mathrm{jk}$ & $0.34 \mathrm{kl}$ & $0.57 \mathrm{D}$ \\
$\mathbf{1 6}$ days & $0.93 \mathrm{e}$ & 0.291 & 0.291 & 0.261 & $0.44 \mathrm{E}$ \\
Mean & 1.32 & 0.56 & 0.46 & 0.41 & \\
\hline
\end{tabular}

$\mathrm{CV}(\%)=14.33$; Ripening stage LSD $(0.05)=0.04$ Storage duration LSD $(0.05)=0.05$; Storage duration*Ripening stage interaction

\section{CONCLUSIONS}

Present experiments conducted for spring harvests revealed that cultivars, ripening stages, and storage durations had significant effects on puncture forces at a $1 \%$ level. The greatest puncture forces were observed in green tomatoes and the lowest puncture forces were observed in red tomatoes. The greatest puncture force was observed in the green ripening stage of 14-193 cultivar and the lowest value was observed in the red ripening stage of the Tybeef cultivar. Considering the storage durations, the lowest puncture force was observed in 16-day storage. The resistance decreased with the progress of ripening stages and storage durations.

Cultivars, replicates, ripening stages, and storage durations had also significant effects on strain values at a $1 \%$ level. The greatest strain value was observed in the green ripening stage of 14-193 cultivar and the lowest value was observed in the red ripening stage of the Tybeef cultivar. Considering the ripening stages, the greatest strain value was observed in green tomatoes. The greatest strain values were observed in green tomatoes and the lowest strain values were observed in red tomatoes since fruit firmness decreased with the progress of ripening. Considering the storage durations, the lowest strain values were observed in 16-day storage. Again, fruit resistance decreased with the progress of ripening and storage.

Ripening stages, replicates and storage durations had significant effects on deformation at a $1 \%$ level, but cultivars did not. The lowest deformation was observed in the green ripening stage of 0-day storage (control) and the greatest deformation was observed in the red ripening stage of 16-day storage. Considering the storage durations, the greatest deformation was observed in 16-day storage. Deformations increased with the progress of ripening and storage.

Cultivars, replicates, ripening stages, and storage durations had significant effects on firmness values at a $1 \%$ level. The greatest firmness was observed in the green ripening stage of 0-day storage (control) and the lowest firmness was observed in the red ripening stage of 16-day storage. Puncture tests revealed that ripening had significant effects on fruit firmness.

As compared to commercial cultivar (Tybeef), 2 candidate cultivars developed by BATEM (14-193 and 14-206), 14-193 as being better, had superior resistance parameters against mechanical damages. It was concluded that harvest at the green ripening stage might minimize potential losses and improve fruit resistance against transportation conditions.

RESUMO: Após a colheita, os produtos agrícolas estão sujeitos a diversos impactos negativos ao longo do caminho até os consumidores. Danos mecânicos como escurecimento da cor, abrasão, cortes ou perfurações na superfície da fruta são irreversíveis e acabam resultando em perdas significativas de qualidade e econômicas. Nos sistemas de produção modernos, apenas uma determinada parte dos produtos chega diretamente do produtor ao consumidor. A maioria desses produtos está sujeita a danos mecânicos por meio de esmagamento, compressão, vibração e impactos semelhantes durante os processos de colheita e pós-colheita. Neste estudo, a cultivar de tomate Tybeef cultivada em estufas experimentais do Bati Akdeniz Agricultural Research Institute (BATEM) (controle) e as cultivares candidatas codificadas 14-193 e 14-206 desenvolvidas por meio de programas de melhoramento do BATEM foram utilizadas como material vegetal. Os parâmetros de resistência dos cultivares de tomate foram determinados em 4 diferentes estágios de maturação (verde, pintado, rosado e vermelho) e 4 diferentes durações de armazenamento (4, 8, 12 e 16 dias). Os parâmetros de resistência diminuíram com o progresso do amadurecimento e durações de armazenamento. Todas as medições e avaliações revelaram que 14-193 cultivares candidatas codificadas eram proeminentes para os parâmetros de resistência. 
PALAVRAS-CHAVE: Data de colheita. Vegetal. Danificar. Qualidade. Sensibilidade.

\section{REFERENCES}

ANONYMOUS, 2018 Calısma raporu [Online]. Turkiye: Antalya Il Tarım ve Orman Mudurluğu, 2018 [consulted 16 March 2018] Available at: https://antalya.tarimorman.gov.tr/Lists/SolMenu/Attachments/72. 2018.

BENTINI, M.; CAPRARA, C.; MARTELLI, R. Physico-mechanical properties of potato tubers during cold storage. Biosystems Engineering, v.104, p.25-32. 2009. https://doi.org/10.1016/j.biosystemseng.2009.03.007

BUI, H.T.; MAKHLOUF, J.; RATTI, C. Postharvest ripening characterization of greenhouse tomatoes.

International Journal of Food Properties, v.13, p.830-846. 2010.

https://doi.org/10.1080/10942910902895234

CAMELO, A.F.; GÓMEZ, P.A. Comparison of color indexes for tomato ripening. Horticultura Brasileira, v.22, p.534-537. 2004. https://doi.org/10.1590/S0102-05362004000300006

CIUPAK, A.; BOŻENA, G.; DZIKI, D. Change in strength of tomato fruit skin during ripening process. Teka Commission of Motorization and Energetics in Agriculture, v.12, p.13-18. 2012.

DESMET, M.; LAMMERTYN, J.; VAN LINDEN, V.; VERLINDEN, B.E.; DARIUS, P.; NICOLA, B.M. The relative influence of stem and fruit properties on stem puncture injury in tomatoes. Postharvest Biology and Technology, v.33, p.101-109. 2004. https://doi.org/10.1016/j.postharvbio.2004.02.001

ERALTAN, F. M. Investigating the effects of variety and duration of storage on mechanical properties of peach. Adana: Çukurova University, 2005. Master's Dissertation.

GARCIA, J.L.; RUIZ-ALTISENT, M.; BARREIRO, P. Factors influencing mechanical properties and bruise susceptibility of apples and pears. J. Agric. Engng. Research, v.61, p.11-17. 1995.

https://doi.org/10.1006/jaer.1995.1025

GEZER, I.; GUNER, M.; DURSUN, E. Bazı sebze ve meyvelerin fiziko-mekanik özelliklerinin belirlenmesi. Ekin Dergisi, v.13, p.70-75. 2000.

HACISEFEROGULLARI, H.; OZCAN, M.; DEMIR, F.; CALISIR, S. Some nutritional and technological properties of garlic (Allium sativum L.). Journal of Food Engineering, v.68, p.463-469. 2005.

https://doi.org/10.1016/j.jfoodeng.2004.06.024

INCE, A.; CEVIK, M.Y.; VURSAVUS, K.K. Effects of maturity stages on textural mechanical properties of tomato. Int. J. Agric \& Biol Engineering, v.9, p.200-206. 2016. https://doi.org/10.3965/j.ijabe.20160906.1999

KABAS, $O$. A research on determination of structural and characteristic properties of some fruit and vegetable packing and sorting facilities in Antalya region. Antalya: Akdeniz University, 2002. Master's Dissertation.

KABAS, O.; OZMERZI, A. Determining the mechanical properties of cherry tomato varieties for handling. Journal of Texture Studies, v.39, p.199-209. 2008. https://doi.org/10.1111/j.1745-4603.2008.00137.x

KABAS, O.; ÇELIK, H.K.; OZMERZI, A.; AKINCI, I. Drop test simulation of a sample tomato with finite element method. J Sci Food Agriculture, v.88, p.1537-1541. 2008. https://doi.org/10.1002/jsfa.3246 
KARA, M.; TURGUT, N. A research on the determination of some important mechanical properties of potato varieties grown in Erzurum region. In: 11th National Congress of Agricultural Mechanization Proceedings, Erzurum, Turkiye, 1998.

KAYNAS, K.; SURMELI, N. Characteristics changes at various ripening stages of tomato fruits stored at different temperatures. Turk. J. Agric. Forestry, v.19, p.277-285. 1995.

MOHSENIN, N.N. Physical properties of plant and animal materials. London: Gordon and Breach Science Publisher, 1986. ISBN 978-0677023007.

NELSON, C.W.; MOHSENIN. N.N. Maximum allowable static and dynamic loads and effect of temperature for mechanical injury in apples. J. Agric. Engng Research, v.13, p.305-317. 1968.

https://doi.org/10.1016/0021-8634(68)90141-8Get

OLORUNDA, A.O.; TUNG, M.A. Simulated transit studies on tomatoes; effect of compressive load, container, vibration, and maturity on mechanical damage. Journal of Food Technology, v.20, p.669-678. 1985. https://doi.org/10.1111/j.1365-2621.1985.tb01964.x

OZDEMIR, M. Mathematical analysis of color changes and chemical parameters of roasted hazelnuts. Istanbul: Istanbul Technical University, 2001. Doctoral Dissertation

PELEG, K.; HINGA. S. Simulation of vibration damage in produce transportation. Transactions of the ASAE, 29:633-641. 1986. https://doi.org/10.13031/2013.30204

PONJIČAN, O.; BABIĆ, M.; BAJKIN, A.; RADOMIROVIĆ, D.; FINDURA, P.; RADOJČIN, M.; PAVKOV, I. Determining physical and mechanical properties of fresh tomato fruit during handling. Journal on

Processing and Energy in Agriculture, v.16, p.98-102. 2012.

SCHOORL, D.; HOLT. J.E. Mechanical damage in agricultural products. A Basis for Management. Agricultural Systems, v.11, p.143-153. 1983. https://doi.org/10.1016/0308-521X(83)90071-9

SIRISOMBOON, P.; TANAKA, M.; KOJIMA, T. Evaluation of tomato textural mechanical properties. Journal of Food Engineering, v.111, p.618-624. 2012. https://doi.org/10.1016/j.jfoodeng.2012.03.007

SITKEI, G. Mechanic of agricultural materials. Budapest: Akademia Kiado, 1986. ISBN 9780444601032

YE, X.; IZAWA, T.; ZHANG, S. Rapid determination of lycopene content and fruit grading in tomatoes using a smart device camera. Cogent Engineering, v.5, p.1-15. 2018. https://doi.org/10.1080/23311916.2018.150449

YURTLU, Y.B.; ERDOGAN, D. Domates çeşitlerinde depolama süresinin bazı mekanik özelliklere etkisinin incelenmesi. Tarım Bilimleri Dergisi, v.11, p. 201-206. 2005. https://doi.org/10.1501/Tarimbil_0000000416 